\title{
Kohesivitas Kelompok Ditinjau Dari Komunikasi Interpersonal Dan Komitmen Organisasi Pada Organisasi Mahasiswa
}

\author{
Hasaniah Zulfiani, Mohammad Risqi, Jhon Mart Ramadhan \\ Pascasarjana Magister Psikologi Profesi Universitas Ahmad Dahlan \\ zhasaniah@gmail.com, ikyrb09@gmail.com, jhonmartramadan@yahoo.com
}

\begin{abstract}
This study aims to determine the relationship between interpersonal communication and organizational commitment with group cohesiveness in student organizations. The sample in this study consisted of 31 members of the Ahmad Dahlan University Faculty Student Executive Board. The method used is correlation. Data collection used group cohesiveness scale, interpersonal communication scale and organizational commitment scale. The analysis technique used is multiple regression analysis with SPSS 16.0 for Windows. The result showed that interpersonal communication and organizational commitment with group cohesiveness was 0.810 with $p=0.000$ (<0.05). It was included thar interpersonal communication and organizational commitment have a relationship to group cohesiveness.
\end{abstract}

Keywords: cohesiveness, interpersonal skill, organizational commitment

\begin{abstract}
Abstrak
Penelitian ini bertujuan untuk mengetahui hubungan antara komunikasi interpersonal dan komitmen organisasi dengan kohesivitas kelompok pada organisasi mahasiswa. Sampel dalam penelitian ini berjumlah 31 anggota Badan Eksekutif Mahasiswa Fakultas Psikologi Universitas Ahmad Dahlan. Metode yang digunakan adalah kuantitatif. Pengumpulan data menggunakan skala kohesivitas kelompok, skala komunikasi interpersonal dan skala komitmen organisasi. Teknik analisis yang digunakan adalah analisis regresi ganda dengan program SPSS 16 for windows. Hasil menunjukkan bahwa komunikasi interpersonal dan komitmen organisasi dengan kohesivitas kelompok sebesar 0.810 dengan $\mathrm{p}=0.000(<0.05)$. Disimpulkan bahwa komunikasi interpersonal dan komitmen organisasi memiliki hubungan terhadap kohesivitas kelompok.
\end{abstract}

Kata kunci: kohesivitas, komunikasi interpersonal, komitmen rganisasi

\section{Pendahuluan}

Peran mahasiswa sebagai agen of change seringkali mendorong mahasiswa untuk membagi prioritas sebagai pelajar di bangku perkuliahan dan turut peka pada lingkungan dalam upaya menjalankan fungsinya sebagai agen perubahan sosial. Dewasa ini mahasiswa-mahasiswa mulai mengaktualisasikan diri untuk terjun aktif pada organisasi kemahasiswaan seperti Badan Eksekutif Mahasiswa (BEM), Unit Kegiatan Mahasiswa (UKM), Komunitas dan sebagainya. Organisasi mahasiswa merupakan organisasi yang beranggotakan mahasiswa yang mewadahi minat bakat dan potensi mahasiswa, sehingga organisasi mahasiswa merupakan tempat yang tepat untuk memaksimalkan potensi, mengasah mental dan mempersiapkan diri dalam dunia organisasi. Menurut Nasrudin (2010) organisasi adalah kumpulan manusia yang diintegrasikan dalam suatu wadah kerjasama untuk menjamin tercapainya tujuan-tujuan yang ditentukan. Untuk mencapai keberhasilan, organisasi mahasiswa membutuhkan kerja sama yang baik di dalam organisasi. Oleh karena itu kekompakan sangat diperlukan untuk mencapai tujuan organisasi.

Kekompakan dalam istilah psikologi yaitu kohesivitas. Menurut Robbin dan Coulter (2004) kohesivitas adalah tingkat sejauh mana anggota-anggota tertarik satu dengan yang lain dan berbagai tujuan dalam kelompok tersebut. Ketertarikan antar anggota tersebut akan membentuk suatu hubungan yang positif seperti interaksi, bertukar pendapat dan menyamakan tujuan untuk meningkatkan kekompakan di dalam organisasi organisasi. Oleh karena itu, organisasi mahasiswa memerlukan kohesivitas yang tinggi dalam mencapai tujuan bersama. Menurut Nitimihardjo dan Iskandar (Huraerah \& Purwanto, 2006) faktor-faktor yang berkaitan dengan tingginya kohesivitas adalah dorongan kepercayaan diantara kelompok, hubungan kooperatif antar individu dalam kelompok, hubungan yang terbuka dan hangat, komunikasi yang efektif di antara anggota kelompok, loyalitas dan tanggung jawab dalam kelompok. Penelitian yang telah dilakukan oleh. Wulansari, Hardjajani, dan 
Nugroho (2013) bahwa terdapat hubungan antara komunikasi efektif dan harga diri dengan kohesivitas kelompok. Komunikasi merupakan hal yang penting bagi anggota dalam menjalankan tugas dan peran dalam organisasi untuk mencapai tujuan bersama.

Berdasarkan wawancara yang dilakukan pada tanggal 13 Oktober 2017 dengan anggota Badan Eksekutif Mahasiswa (BEM) Fakultas Psikologi Ahmad Dahlan menjelaskan bahwa komunikasi dan koordinasi dari atasan ke bawahan serta sebaliknya menjadi hal yang penting untuk membangun kekompakan pada organisasi Badan Eksekutif Mahasiswa (BEM). Kohesivitas BEM ditandai dengan keterlibatan anggota - anggota untuk menyukseskan program kerja organisasi dan secara bersamasama untuk mencapai tujuan organisasi serta bertanggung jawab untuk melaksanakan tugas dan fungsi masing-masing. Dalam menjalan program kerja anggota BEM saling bekerjasama dan saling memahami serta berkomitmen untuk tetap berada pada organisasi hingga masa periode berakhir. Lebih lanjut dalam menjalankan fungsinya, anggota organisasi BEM dipimpin oleh ketua BEM, dan pengurus harian lainnya seperti sekretaris dan bendahara. Terdapat beberapa bidang dalam organisasi BEM yang dipimpin oleh kepala bidang masing-masing dan berfungsi untuk mengatur anggota bidang dalam menjalankan program dan memberikan motivasi dan perhatian kepada anggota agar tetap menjaga kekompakan dalam menjalankan tugas dan tanggung jawab serta mencapai tujuan organisasi secara bersama.

\section{Kohesivitas kelompok}

Kekompakan atau kohevitas menjadi hal yang diperlukan anggota dalam mencapai tujuan organisasi. Forsyth (2014) menjelaskan kohesivitas kelompok adalah bentuk integritas individu, solidaritas antar individu dan bentuk kesatuan di dalam kelompok. Menurut Taylor, Peplau \& Sears (2009) kohesivitas kelompok merupakan bentuk kekuatan positif dan kekuatan negatif yang terdapat di dalam kelompok. Menurut Forsyth (2014) aspek-aspek kohesivitas kelompok adalah : a. Kohesi sosial adalah daya tarik antara satu sama lain diantara anggota sebagai bentuk keutuhan kelompok. b. Kohesi tugas adalah berbicara mengenai komitmen dan tanggung jawab individu pada kelompok untuk bekerjasama mewujudkan tujuan bersama. c. Kohesi kolektif merupakan sejauhmana individu merasakan kentalnya persaudaraan, rasa saling memahami, menyadari peran, rasa saling membutuhkan dan rasa saling memiliki individu masing-masing. d. Kohesi emosi merupakan tingkat intensitas emosional di dalam sebuah kelompok dan kondisi emosional setiap individu ketika berada dalam kelompok. e. Kohesi struktural adalah kesatuan kelompok yang diperoleh dari kesamaan norma, kepedulian individu akan aturan kelompok, kuat tidaknya hubungan antar anggota.

\section{Komunikasi interpersonal}

Kohesivitas dapat ditingkatkan melalui komunikasi yang dibangun antar anggota atau komunikasi interpersonal dan sebaliknya apabila komunikasi kurang baik dapat memicu berkurangnya kohesivitas di dalam organisasi. Penelitian yang telah dilakukan oleh. Wulansari, Hardjajani, dan Nugroho (2013) bahwa terdapat hubungan antara komunikasi efektif dan harga diri dengan kohesivitas kelompok. Komunikasi merupakan hal yang penting bagi anggota dalam menjalankan tugas dan peran dalam organisasi untuk mencapai tujuan bersama. Tersendatnya sebuah komunikasi antar anggota memberi dampak negatif pada kohesivitas sebuah organisasi sebagai kelompok, sehingga dapat mempengaruhi pencapaian tujuan dan target dalam sebuah kelompok. Komunikasi interpersonal menurut De Vito (1997) adalah sebuah proses komunikasi pengiriman pesan yang terjadi antara individu terhadap individu lainnya dengan effect dan feedback secara langsung. De Vito (1997) menjelaskan ada lima aspek dalam komunikasi interpersonal adalah: a) Keterbukaan adalah keinginan dalam diri individu untuk membuka diri (kesediaan) untuk berinteraksi dengan individu lain. b) Empati adalah memahami, merasakan apa yang dirasakan oleh orang lain rasakan.. Pemenuhan empati dapat dilakukan secara verbal atau non verbal.c) Sikap mendukung meliputi tiga hal. Pertama bersikap deskriptif tidak menggunakan komunikasi evaluatif. Kedua, spontanitas sebagai kemampuan seseorang menciptakan suasana mendukung dengan memunculkan sifat spontan dan terbuka. Ketiga, provosionalisme artinya bersikap tentatif mau bersikap terbuka dengan mendengarkan pandangan yang berseberangan dalam artian lain fleksibel sebagai rekan dalam berkomunikasi atau dikenal dengan bertukar pendapat atau diskusi. d) Sikap Positif (positiveness), yaitu sikap positif dalam diri yang dapat ditularkan dari individu satu dengan lain saat berinteraksi dengan memandang diri sebagai pribadi positif dan menghargai keberadaan orang lain. Sedangkan dorongan positif secara verbal berbentuk pujian atau 
penghargaan, terdiri atas perilaku yang diharapkan, nikmati dan banggakan. e) Kesetaraan adalah sikap individu saling menerima, menghargai adanya kesamaan sebagai komunikan dan komunikator. Selain itu, kesetaraan merupakan kemampuan dalam menyikapi, memahami perbedaan untuk kesamaan nilai.

\section{Komitmen organisasi}

Selain itu, kohesivitas kelompok dapat dipengaruhi oleh komitmen organisasi. Hasil penelitian yang dilakukan oleh Purwaningtyastuti, Wismanto, dan Suharsono (2012) bahwa terdapat hubungan antara komitmen organisasi dengan kohesivitas kelompok. Meyer dan Allen (Robbin dan Judge, 2009) mengemukakan bahwa komitmen organisasi dapat dijelaskan sebagai kondisi psikologis yang menggambarkan hubungan karyawan dengan organisasi dan mempengaruhi keputusan karyawan ntuk melanjutkan keanggotaan di organisasi tersebut. Menurut Allen dan Meyer (Robbin and Judge, 2009) menjelaskan bahwa aspek-aspek dari komitmen organisasi : a) Komitmen Affective adalah komitmen yang berhubungan dengan keinginan secara emosional individu dengan organisasi, untuk aktif dan menjalin keterlibatan terhadap nilai-nilai di dalam kelompok. b) Komitmen continuance, yaitu komitmen yang didasari oleh kesadaran akan hal-hal yang akan menjadi tanggungan jika tidak bergabung dengan organisasi. c) Komitmen normative, yaitu komitmen yang berdasarkan perasaan wajib sebagai anggota organisasi untuk tetap tinggal dalam organisasi. Disini terjadi juga internalisasi norma-norma kelompok yang akan diaplikasikan oleh individu.

\section{Metode Penelitian}

Penelitian ini menggunakan metode korelasional, Subjek dalam penelitian ini adalah anggota Badan Eksekutif Mahasiswa (BEM) Fakultas Psikologi Universitas Ahmad Dahlan berjenis kelamin laki-laki dan perempuan sebanyak 31 orang. Pengumpulan data penelitian menggunakan tiga skala yaitu skala kohesivias kelompok, skala komitmen organisasi dan skala komunikasi interpersonal.

Skala kohesivitas kelompok disusun bersadarkan aspek-aspek yang dikemukan oleh Forsyth (2012) yakni kohesi sosial, kohesi tugas, kohesi kolektif, kohesi emosi, dan kohesi struktural. Skala komunikasi interpersonal yang digunakan dalam penelitian ini disusun berdasarkan aspek-aspek dari De Vito (1997), yaitu keterbukaan, empati, dukungan, kepositifan, dan kesamaan. Skala komitmen organisasi yang digunakan dalam penelitian ini diadaptasi dari skala Jaros (2007) berdasarkan aspekaspek yang dikemukan oleh Allen dan Meyer (Robbin \& Judge, 2009) yakni komitmen affective, komitmen continuance, dan komitmen normative.

Pada skala ini terdapat empat alternatif jawaban yang disediakan pada penelitian ini, yaitu Sangat Setuju (SS) bernilai 4, Setuju (S) bernilai 3, Tidak Setuju (TS) bernilai 2, Sangat Tidak Setuju (STS) bernilai 1. Sedangkan pada aitem unfavorable skor yang diberikan yaitu Sangat Setuju (SS) bernilai 1, Setuju (S) bernilai 2, Tidak Setuju (TS) bernilai 3, Sangat Tidak Setuju (STS) bernilai 4.

Teknik analisis data yang digunakan adalah analisis regresi ganda. Analisis regresi ganda digunakan untuk menguji nilai pengaruh dua variable bebas atau lebih terhadap varabel tergantung (Suseno, 2012). Perhitungan statistik ini dilakukan dengan komputerisasi melalui bantuan program Statistical Product and Service Solution (SPSS) 16.0 for Windows.

\section{Hasil dan Pembahasan}

Hasil analisis reliabilitas pada ketiga skala menggunakan Alpha Cronbach diperoleh bahwa ketiga skala dapat digunakan sebagai alat pengumpul data. Reliabilitas skala kohesivitas kelompok menunjukkan alpha cronchbach sebesar 0.916 dengan 27 aitem. Reliabilitas ksala komunikasi interpersonal menujukkan alpha Cronbach sebesar 0.877 dengan 27 aitem dan skala komitmen organisasi menunjukkan alpha croncbach sebesar 0.809 dengan 24 aitem.

Sebelum dilakukan uji hipotesis dengan menggunakan analisis regresi ganda, maka dilakukan uji asumsi yakni uji normalitas dan uji multikolinearitas. Hal ini dilakukan untuk mengetahui bahwa data subjek terdistribusi normal dan uji multikolinearitas untuk mengetahui apakah masing-masing variabel bebas tidak mengalami multikolinear terhadap variabel tergantung. Berikut hasil uji asumsi normalitas dan multikolinearitas. 
Tabel 1. Hasil Uji Normalitas

\begin{tabular}{lccc}
\hline \multicolumn{1}{c}{ Variabel } & $\boldsymbol{K S}-\boldsymbol{z}$ & $\boldsymbol{p}$ & Keterangan \\
\hline Kohesivitas Kelompok & 0.894 & 0.401 & Normal \\
Komunikasi Interersonal & 0.810 & 0.529 & Normal \\
Komitmen Organisasi & 0.592 & 0.874 & Normal \\
\hline
\end{tabular}

Tabel di atas menunjukkan bahwa skala kohesivitas kelompok adalah p sebesar $0.401(p>0.05)$ dan nilai kolmogorov-Smirnov $Z$ sebesar 0.894, artinya sebaran data tersebut terdistribusi normal. Sedangkan data pada skala komunikasi interpersonal adalah p sebesar 0.529 (p > 0.05) dan nilai kolmogorov-Smirnov $Z$ sebesar 0.810 artinya sebaran data tersebut terdistribusi normal serta data pada skala komitmen organisasi adalah p sebesar $0.874(\mathrm{p}>0.05)$ dan nilai kolmogorov-Smirnov $Z$ sebesar 0.592 artinya sebaran data tersebut terdistribusi normal.

Tabel 2. Hasil Uji Multikolinearitas

\begin{tabular}{cccc}
\hline Variabel & Tolerance & VIF & Keterangan \\
\hline Komitmen Organisasi & 0.598 & 1.671 & Tidak terjadi multikolinear \\
Komunikasi Interersonal & 0.598 & 1.671 & Tidak terjadi multikolinear \\
\hline
\end{tabular}

Hasil uji multikolinearitas menunjukkan nilai 0,598 , dengan VIF $=1,671$ pada skala komitmen organisasi, sedangkan skala komunikasi interpersonal sebesar 0,58 , dengan VIF $=1,671$. Hal ini berarti bahwa dapat tidak terjadi multikolinear pada kedua variable tersebut.

Setelah uji asumsi, kemudian dilakukan uji hipotesis dengan metode analisis regresi ganda. Hasil analisis regresi ganda diperoleh hasil penelitian sebagai berikut:

Tabel 3. Hail Uji Hipotesis

\begin{tabular}{cccccc}
\hline Variabel & Correlation & $\begin{array}{c}\text { Asymp. Sig } \\
(\text { 2-tailed })\end{array}$ & $\boldsymbol{R}$ square & Prosentase & Hipotesis \\
\hline $\begin{array}{c}\text { Komunikasi \& } \\
\text { komitmen } \\
\text { Komunikasi }\end{array}$ & 0.810 & 0.000 & 0.656 & $65.6 \%$ & Terima \\
$\begin{array}{c}\text { Interersonal } \\
\text { Komitmen } \\
\text { Organisasi }\end{array}$ & 0.795 & 0.000 & 0.632 & $63.2 \%$ & Terima \\
\hline
\end{tabular}

Berdasarkan analisis hasil analisis regresi diperoleh nilai koefisien korelasi $r_{x y}(R)=0.810$ dengan taraf signifikansi $(\mathrm{p})$ sebesar $0.000(\mathrm{p}<0.05)$, maka hipotesis mayor diterima. Hal ini menunjukkan ada hubungan yang sangat signifikan antara komunikasi interpersonal dan komitmen organisasi dengan kohesivitas kelompok. Hasil lain diperoleh adalah nilai koefesien determinasi ( $R$-Square) sebesar 0.656 yang berarti bahwa komunikasi interpersonal dan komitmen organisasi memiliki pengaruh sebesar $65.6 \%$ terhadap kohesivitas kelompok, sedangkan sisanya sekitar $34,4 \%$ dipengaruhi oleh variabel lain.

Hasil analisis statitik menggunakan korelasi analisis regresi ganda menunjukkan bahwa koefisien korelasi $\mathrm{r}_{\mathrm{xy}}(\mathrm{R})=0.795$ dengan taraf signifikansi $(\mathrm{p})$ sebesar $0.000(\mathrm{p}<0.05)$, maka hipotesis diterima. Hal ini menunjukkan bahwa ada hubungan positif antara komunikasi interpersonal dengan kohesivitas kelompok. Nilai koefisien determinasi yang ditunjukkan oleh $R$-Square adalah 0.632. Angkat tersebut menunjukkan bahwa komunikasi interpersonal memberikan sumbangan efektif sebesar $63.2 \%$. Hasil analisis lainnya menunjukkan bahwa koefisien korelasi $\mathrm{R}$ sebesar 0.622 dengan taraf signifikansi (p) sebesar $0.000(\mathrm{p}<0,05)$, maka hipotesis diterima. Hal ini menunjukkan bahwa ada hubungan yang sangan signifikan antara komitmen organisasi dengan kohesivitas kelompok. Nilai koefisien determinasi yang ditunjukkan oleh $R$-Square adalah 0.387. Angka tersebut menunjukkan bahwa komitmen organisasi memberikan pengaruh sebesar 38.7\%. Berdasarkan analisis data, maka hipotesis yang telah diajukan dapat diterima, yaitu ada hubungan positif yang sangat signifikan antara komunikasi interpersonal dan komitmen organisasi dengan kohesivitas kelompo. Semakin tinggi 
komunikasi interpersonal dan komitmen organisasi maka semakin tinggi pula kohesivitas kelompok. Sebaliknya, semakin rendah komunikasi interpersonal dan komitmen organisasi maka semakin rendah pula kohesivitas kelompok.

Hal ini berarti bahwa anggota organisasi mahasiswa memiliki komunikasi interpersonal yang baik dapat mendorong mahasiswa untuk meningkatkan kohesivitas kelompoknya, seperti adanya keterbukaan, antar anggota, saling memahami, saling memberi dukungan, saling menghargai dan saling menerima perbedaan. Tingginya tingkat kohesivitas kelompok pada organisasi mahasiswa menunjukkan bahwa mereka telah membuat daya tarik antara satu sama lain diantara anggota kelompok, mampu berbicara mengenai komitmen dan tanggung jawab individu pada kelompok, memiliki rasa persaudaraan, saling memahami, saling membutuhkan dan rasa saling memiliki serta menjadi kesatuan kelompok yang diperoleh dari kesamaan norma dan hubungan antar anggota. Hasil penelitian ini menunjukkan bahwa komunikasi interpersonal berhubungan secara positif dengan kohesivitas kelompok. Hal ini sejalan dengan pendapat Jarvis (Hall, 2007) yang menyatakan komunikasi interpersonal adalah salah satu faktor yang dapat mempengaruhi kohesivitas sebuah kelompok. Kelompok yang kohesivitasnya tinggi, diasumsikan sebagai kelompok yang melakukan komunikasi antar anggota dapat terjalin dengan baik sebagai suatu kesatuan. Lebih lanjut Johnson dan Johnson (2012) dalam penelitiannya menyimpulkan efektifitas komunikasi interpersonal yang dibangun antar individu pada kelompok akan mendorong terjadinya kerjasama antara anggota di dalam suatu kelompok.

Selain itu, Hasil penelitian ini menunjukkan bahwa komitmen organisasi juga dapat mempengaruhi kohesivitas kelompok. Penelitian ini didukung dengan hasil penelitian yang telah dilakukan Purwaningtyastuti, Wismanto, \& Suharsono (2012) pada karyawan di Universitas Semarang, ada hubungan antara komitmen terhadap organisasi dengan kohesivitas kelompok. Hal ini berarti individu memiliki komitmen secara emosional untuk aktif dan terlibat pada organisasi, memiliki kesadaran akan hal-hal yang akan menjadi tanggungan serta menginternalisasi norma-norma kelompok dalam dirinya, sehingga dapat meningkatkan kekompakan dalam suatu kelompok atau organisasi. Lebih lanjut Purwaningtyas Wismanto, \& Suharsono (2012) mengemukakan bahwa organisasi dapat menciptakan komitmen afektif diantara anggota, dimana di dalamnya terdapat suatu situasi rasa memiliki, loyalitas, kesetiakawanan, rasa aman, rasa diterima dan dihargai serta perasaan berhasil dalam diri individu yang memiliki keterikatan satu sama lain.

Hasil penelitian ini juga membuktikan bahwa komunikasi interpersonal merupakan faktor yang paling mempengaruhi kohesivitas kelompok. Hal ini dapat dilihat bahwa nilai sumbangan efektif dari komunikasi interpersonal terhadap kohesivitas kelompok yaitu sebesar 63,2\%. Peran komunikasi interpersonal terhadap kohesivitas kelompok memiliki pengaruh lebih besar dibandingkan dengan komitmen organisasi terhadap kohesivitas kelompok. Dengan demikian, dapat dikatakan bahwa individu dalam organisasi yang memiliki kohesivitas kelompok yang tinggi adalah individu yang memiliki komunikasi interpersonal yang baik.

\section{Kesimpulan}

Berdasarkan hasil analisis data, maka dapat disimpulkan bahwa ada hubungan yang signifikan antara komunikasi interpersonal dan komitmen organisasi dengan kohesivitas kelompok pada organisasi mahasiswa. Semakin tinggi komunikasi interpersonal dan komitmen organisasi, maka semakin tinggi pula kohesivitas kelompok. Sebaliknya, semakin rendah komunkasi interpersonal dan komitmen organisasi, maka semakin rendah pula kohesivitas kelompok pada organisasi mahasiswa. Selain itu, didapatkan hasil bahwa komunikasi interpersonal memiliki pengaruh lebih besar terhadap kohesivitas kelompok dibandingkan dengan komitmen organisasi terhadap kohesivitas kelompok, sehingga komitmen organisasi lebih berperan dalam upaya peningkatan kohesivitas kelompok.

\section{Daftar Pustka}

[1] DeVito, A. J. (1997). Komunikasi Antar Manusia. Jakarta: Professional Books.

[2] Forsyth, D. R. (2014). Group Dynamics ( $6^{\text {th }}$ ed.). Belmont, CA: Wadsworth Cengage Learning

[3] Hall, A. (2007). Sport Psychology: Building Group Cohesion, Performance, and Trust in Athletic Teams. Journal PSY 8840-Sport Psychology Capella University.

[4] Huraerah., \& Purwanto. (2006). Dinamika Kelompok. Bandung: PT Refika Aditama 
[5] Johnson, W. D., \& Johnson, F. P. (2012). Dinamika Kelompok Edisi Kesembilan Teori dan Keterampilan. Jakarta: PT Indeks

[6] Kartono, K. (2002). Psikologi Sosial Untuk Manajemen. Perusahaan dan Industri. Jakarta: PT.RajaGrafindo Persada

[7] Nasrudin, E. (2010). Psikologi Manajemen. Bandung: CV Pustaka Setia

[8] Purwaningtyastuti., Wismanto, B., \& Suharsono, M,. (2012). Kohesivitas Kelompok Ditinjau dari Komitmen Terhadap Organisasi dan Kelompok Pekerjaan. Kajian Ilmiah Psikologi, 2(1),179-182.

[9] Robbins, S. \& Judge, T. (2009). Perilaku Organisasi. Jakarta: Salemba Empat.

[10] Robbins., \& Coulter, M. (2004). Manajemen Edisi Bahasa Indonesia. Jakarta: PT.Indeks.

[11] Suseno, M. N. (2012). Statistika: Teori dan aplikasi untuk penelitian Ilmu Sosial dan Humaniora. Yogyakarta: Ash-Shaff

[12] Wulansari, H., Hardjajani, T., \& Nugroho, A. A. (2013). Hubungan antara komunikasi yang efektif dan harga diri dengan kohesivitas kelompok pada pasukan suporter solo sejati (pasoepati). Jurnal Ilmiah Psikologi Candrajiwa, 1(4), 1-13. 